\title{
The Methodical Approach of the Substantiation of the Evaluation Indicators System of the Agro-Industrial Complex Development
}

\author{
Bogdan Iegorov ${ }^{1}$, Yurii Kravchyk ${ }^{2, *}$, Serhiy Rybalko ${ }^{3}$, Iryna Ivashkiv ${ }^{4}$, Anton Chub ${ }^{5}$ \\ ${ }^{1}$ Department of Feed Technology and Biofuels, Odessa National Technological University, 112 Kanatna Str., Odessa, 65039, Ukraine \\ ${ }^{2}$ Department of Economics, Management and Administration, Khmelnytskyi National University, 11 Institutskaya Str., \\ Khmelnytskyi, 29000, Ukraine \\ ${ }^{3}$ Department of Economic Theory and Financial and Economic Security, Odessa National Technological University, 112 Kanatna Str., \\ Odessa, 65039, Ukraine \\ ${ }^{4}$ Precarpathian State Agricultural Experimental Station, Institute of Agriculture of the Carpathian Region NAAS, 5 Hrushevskogo Str., \\ Oboroshino Village, Pustomytivskii district, Lvivska region, 81115, Ukraine \\ ${ }_{5}^{5}$ Department of Management, IHE “Academician Yuriy Bugay International Scientific and Technical University”, 3 lane \\ Magnitogorsky, Kyiv, 02000, Ukraine
}

Received September 7, 2021; Revised October 13, 2021; Accepted November 7, 2021

\section{Cite This Paper in the following Citation Styles}

(a): [1] Bogdan Iegorov, Yurii Kravchyk, Serhiy Rybalko, Iryna Ivashkiv, Anton Chub, "The Methodical Approach of the Substantiation of the Evaluation Indicators System of the Agro-Industrial Complex Development," Universal Journal of Agricultural Research, Vol. 9, No. 5, pp. 191 - 199, 2021. DOI: 10.13189/ujar.2021.090506.

(b): Bogdan Iegorov, Yurii Kravchyk, Serhiy Rybalko, Iryna Ivashkiv, Anton Chub (2021). The Methodical Approach of the Substantiation of the Evaluation Indicators System of the Agro-Industrial Complex Development. Universal Journal of Agricultural Research, 9(5), 191 - 199. DOI: 10.13189/ujar.2021.090506.

Copyright $\odot 2021$ by authors, all rights reserved. Authors agree that this article remains permanently open access under the terms of the Creative Commons Attribution License 4.0 International License

\begin{abstract}
In this study, the authors propose a methodological approach to substantiate the evaluation indicators system of the regional development of the agro-industrial complex. The methodological basis for establishing the evaluation indicators system is determined, which is based on the principles of systematization, universality and consistency of evaluation indicators. Based on the generalized list of prior evaluation indicators, the evaluation indicators system is substantiated using the expert method. For each indicator, its approval by experts is determined, as an example, the agreement of experts on capital investment in agriculture, hunting and related services, as a percentage of total investment in the region. The structural-logical scheme of the structure of the evaluation system formation of the agro-industrial complex of the regions is offered. The proposed system of evaluation of the agro-industrial complex provides for the definition of such areas as follows: industries that produce means of production for agriculture and other industries that provide services to agriculture; Agriculture; industries for processing and preservation of agricultural products; production and social infrastructure.
\end{abstract}

Keywords Agro-industrial Complex, Region, Regional Development, Agriculture, Sustainable Development

\section{Introduction}

Modern problems of sustainable development and growing unsatisfied consumer demand require research on the development of agro-industrial complex. The agro-industrial complex plays an important role in the development of the state. Each country, as well as its regions, has specific features due to many circumstances. Ukraine is no exception and this requires research and substantiation of methodological bases for the formation of evaluation indicators of the agro-industrial complex. The study of publications allows the authors to conclude that there is no single unified system for assessing the development of the agro-industrial complex, and there is no single point of view on their justification. The difficulty of assessing the development of the agro-industrial complex is due to the fact that it combines 
a large number of different industries.

The purpose of the article is to substantiate the evaluation indicators system of the regional development of the agro-industrial complex of Ukraine. To achieve this goal, the authors set and solved the following tasks:

- methodologically substantiated principles of the selection of estimated indicators of the regional development of the agro-industrial complex;

- a general list of evaluation indicators for further systematization and selection has been established;

- the evaluation indicators system was coordinated using the expert-statistical method.

Many scientific works of domestic and foreign scientists are devoted to the development of the agro-industrial complex. Scientists [1-2] emphasize that the processes taking place in the modern economic community require new solutions and approaches related to integration processes in the agricultural sector. The author of the article [3] analyzes the reforms in the field of the agro-industrial complex and evaluates their effectiveness; based on the study, conclusions are formulated on the main most optimal and necessary areas of state regulation.

The study [4] evaluates and analyzes the gross domestic product (GDP) of agribusiness for 63 countries and the rest of the world and demonstrates the results and links with the Human Development Index (HDI). The aim of the article [5] is to study the decriminalization of the agro-industrial complex as the most important factor of food security, as well as a way to solve problems affecting the state of food security, the problem of legal support of national priorities related to food independence. The article [6] presents the results of the study of the state of the innovation stimulation in the agro-industrial complex, and based on these results, the authors proposed a conceptual and logical model of innovation in the agro-industrial complex, which ensures the development of agricultural enterprises based on science-intensive technologies.

The authors of articles [7-11] with the help of comparative analysis and calculation of differentiation coefficients characterize the degree of difference in the development of the region's agro-industrial complex in the conditions of sanction pressure and in the conditions of sustainable development. In the articles [12-17], the authors consider the peculiarities of the functioning of the agro-industrial complex in digital economy. The article examines the largest market participants in the agro-industrial complex who have joined forces to digitize agriculture. The authors [18] present the main characteristics of the sustainability of the agro-industrial complex, which allows providing a comprehensive assessment of its condition to justify a certain structural model of the strategy of sustainable development of agriculture with changing the level of environmental parameters.

The authors of the articles [19-21] assess the impact of negative factors and suggest the development of engineering, social and transport infrastructure and the improvement of the situation on the labor market in rural areas as one of the solutions. It is proved within the article that the support of the agro-industrial complex is important and will provide an opportunity to solve existing problems. Articles [22-26] are based on the definition of key principles for building a system of efficiency of innovation activities of agro-industrial companies and the study of economic security in conditions of intensified competition.

However, despite the considered researches of leading scientists it should be noted that the methodical approach of the substantiation of the evaluation indicators system of the agro-industrial complex development needs the further studying and the analysis.

\section{Materials and Methods}

The substantiation of evaluation indicators is preceded by the determination of the methodological basis for their establishment, which includes the principles of criterion selection of evaluation indicators. The main principles that must be met by evaluation indicators are:

- the principle of systematization - provides for the separation of the general set of evaluation indicators that can fully and comprehensively characterize the subject of research, namely the process of development of agro-industrial complex of regions, reflect specific features and represent a certain systemic structure of grouping indicators;

- universality - provides an opportunity to use a system of evaluation indicators for all regions of the country and fully describe the development of all areas of the agro-industrial complex. In addition, the principle of universality provides for the availability of quantitative measurement and the possibility of their rationing and comparison with statistics and estimates of international observations;

- consistency, which provides for the content of each indicator and its logical relationship with the evaluation indicators system in the absence of duplication, which can also be detected by correlation calculations.

The principle of systematization, universality and coherence of the estimated indicators of development of the agro-industrial complex makes it possible to make accurate calculations and to compare them, to eliminate the errors associated with the primary data entered for evaluation.

\section{Results and Discussions}

The conducted research on the assessment of the development of the agro-industrial complex made it possible to form an initial list of evaluation indicators, which is presented in Table 1 . 
Table 1. Initial list of evaluation indicators for assessing the level of the regional development of agro-industrial complexes

\begin{tabular}{|c|c|}
\hline Indicators for assessing the level of the regional development of agro-industrial complexes & $\begin{array}{c}\text { Scope of } \\
\text { evaluation }\end{array}$ \\
\hline Capital investment in agriculture, hunting and related services, $\%$ of total investment in the region & \multirow{9}{*}{$\begin{array}{c}\text { The sphere of } \\
\text { industries that } \\
\text { produce means of } \\
\text { production for } \\
\text { agriculture }\end{array}$} \\
\hline Purchase of new agricultural machinery by agricultural enterprises, pcs. & \\
\hline Innovatively active enterprises, in total, units & \\
\hline Sale of compound feeds to agricultural enterprises, thousand centners & \\
\hline Purchase of energy materials by agricultural enterprises, million $\mathrm{m}^{3}$ & \\
\hline Purchase of mineral fertilizers by agricultural enterprises, thousand $\mathrm{c}$. & \\
\hline Purchase of plant protection products by agricultural enterprises, thousand tons (thousand liters) & \\
\hline Availability of tractors, combines and agricultural machinery at agricultural enterprises, at the end of the year, pcs. & \\
\hline Sale of petroleum products to agricultural enterprises, thousand & \\
\hline Agricultural production indices, in $\%$ to the previous year & \multirow{32}{*}{$\begin{array}{c}\text { Sphere of } \\
\text { agriculture }\end{array}$} \\
\hline Livestock production indices, in $\%$ to the previous year & \\
\hline Meat production (in slaughter mass), thousand tons & \\
\hline Milk production, thousand tons & \\
\hline Egg production, mln & \\
\hline Purchase of plant protection products by agricultural enterprises, thousand tons (thousand liters) & \\
\hline Availability of tractors, combines and agricultural machinery at agricultural enterprises, at the end of the year, pcs. & \\
\hline Sale of petroleum products to agricultural enterprises, thousand & \\
\hline Agricultural production indices, in $\%$ to the previous year & \\
\hline Livestock production indices, in \% to the previous year & \\
\hline Meat production (in slaughter mass), thousand tons & \\
\hline Milk production, thousand tons & \\
\hline Egg production, mln & \\
\hline Livestock products (at constant prices in 2010), UAH million & \\
\hline The level of profitability of beef production for meat, in $\%$ & \\
\hline The level of profitability of pork production for meat, in $\%$ & \\
\hline The level of profitability of poultry production for meat, in $\%$ & \\
\hline The level of profitability of milk production, in $\%$ & \\
\hline The level of profitability of chicken egg production, in $\%$ & \\
\hline Crop production indices, in $\%$ to the previous year & \\
\hline Production of cereals and legumes, thousand tons & \\
\hline Production of sugar beets (factory), thousand tons & \\
\hline Sunflower production, thousand tons & \\
\hline Potato production, thousand tons & \\
\hline Vegetable production, thousand tons & \\
\hline Production of fruits and berries, thousand tons & \\
\hline Crop products (at constant 2010 prices), UAH million & \\
\hline The level of profitability of production of cereals and legumes, in $\%$ & \\
\hline The level of profitability of sugar beet production (factory), in $\%$ & \\
\hline The level of profitability of sunflower seed production, in $\%$ & \\
\hline The level of profitability of potato production, in $\%$ & \\
\hline The level of profitability of open-ground vegetable production, in $\%$ & \\
\hline
\end{tabular}


Table 1. Continued

\begin{tabular}{|c|c|}
\hline Production of sausages, thousand tons & \multirow{10}{*}{$\begin{array}{c}\text { Sphere of } \\
\text { processing } \\
\text { industry }\end{array}$} \\
\hline Production of fatty cheeses, thousand tons & \\
\hline Production of unrefined sunflower oil and its fractions, thousand tons & \\
\hline Production of processed liquid milk (pasteurized, sterilized, homogenized, rendered, peptized), thousand tons & \\
\hline Production of yogurt and other fermented or fermented milk and cream, thousand tons & \\
\hline Flour production, thousand tons & \\
\hline Production of bread and bakery products, short-term storage, thousand tons & \\
\hline Production of white crystalline sugar, thousand tons & \\
\hline Production of food, beverages and tobacco, in $\%$ to the previous year & \\
\hline Textile production, production of clothing, leather, leather products and other materials, in $\%$ to the previous year & \\
\hline Commissioning of housing in rural areas, thousand $\mathrm{m}^{2}$ of total area & \multirow{10}{*}{$\begin{array}{c}\text { Sphere of } \\
\text { production and } \\
\text { social } \\
\text { infrastructure }\end{array}$} \\
\hline Capital investment in transport, warehousing, \% of total investment in the region & \\
\hline Capital investment in temporary accommodation and catering, $\%$ of total investment in the region & \\
\hline Capital investment in information and telecommunications, $\%$ of total investment in the region & \\
\hline Capital investment in education, $\%$ of total investment in the region & \\
\hline Capital investments in health care and social assistance, $\%$ of total investments in the region & \\
\hline Capital investments in professional, scientific and technical activities, $\%$ of total investments in the region & \\
\hline Retail trade, except of motor vehicles and motorcycles, mln. UAH & \\
\hline $\begin{array}{l}\text { Internal current expenses for scientific and scientific-technical works performed by own organizations of scientific } \\
\text { organizations, in actual prices, thousand UAH }\end{array}$ & \\
\hline Capital investments in wholesale and retail trade, repair of motor vehicles, $\%$ of total investments in the region & \\
\hline
\end{tabular}

Source: compiled and summarized by the authors

According to the initial list of evaluation indicators, their choice is substantiated and systematized using the expert method. Seventeen highly qualified specialists in the field of agro-industrial production were involved in the examination. The number of specialists was determined using the formula:

$$
0.5 \cdot\left(\frac{3}{e}+5\right)
$$

where, $\mathrm{e}-$ change in the estimate corresponding to $\mathrm{e}=$ 0.11 , it is a constant value that is determined according to the Saati scale and makes it possible to determine the number of experts. The rating scale for experts is from 0.006 to 0.060 with a gradation of 0.006 . In our case, given that the experts involved seventeen people, we have:

$$
0.5 \cdot\left(\frac{3}{0.11}+5\right)=16.136
$$

Each of the presented indicators given in Table 1 is coordinated. In the form of a detailed sample, we give an example of approval by experts of the assessment for the evaluation indicator "Capital investment in agriculture, hunting and related services, $\%$ of total investment in the region", which belongs to the industries that produce means of production for rural farms (Table 2). 
Table 2. Substantiation of coordination by experts of a choice of an estimation indicator of development of an agro-industrial complex of region

\begin{tabular}{|c|c|c|c|c|c|c|c|c|c|c|c|c|c|c|c|c|c|c|}
\hline Value & & & & & & & & Expe & t assess & nents & & & & & & & & Explanation \\
\hline $\begin{array}{l}\text { Experts in decision-making in } \\
\text { the order of ranking }\end{array}$ & 1 & 2 & 3 & 4 & 5 & 6 & 7 & 8 & 9 & 10 & 11 & 12 & 13 & 14 & 15 & 16 & 17 & $\begin{array}{c}\begin{array}{c}\text { Seventeen experts were } \\
\text { elected }\end{array} \\
\end{array}$ \\
\hline $\begin{array}{c}\text { Expert assessments to } \\
\text { substantiate the evaluation } \\
\text { indicator }\end{array}$ & 0,006 & 0,024 & 0,012 & 0,024 & 0,030 & 0,012 & 0,006 & 0,012 & 0,024 & 0,012 & 0,030 & 0,036 & 0,012 & 0,024 & 0,012 & 0,042 & 0,054 & $\begin{array}{l}\text { Built dependence on the } \\
\text { rank of the selected expert }\end{array}$ \\
\hline \multirow{16}{*}{ Rank correlation } & & + & + & + & + & + & + & + & 0 & + & + & + & + & + & + & + & + & \multirow{16}{*}{$\begin{array}{l}\text { If } \mathrm{Rx} \text { is more than } 0.3 \\
\text { modulo, the examination is } \\
\text { accepted as positive } \\
\text { (agreed evaluation) }\end{array}$} \\
\hline & & & - & 0 & - & + & - & - & 0 & - & + & - & + & 0 & - & + & + & \\
\hline & & & & + & + & 0 & - & 0 & + & 0 & + & + & 0 & + & 0 & + & + & \\
\hline & & & & & - & - & + & - & - & 0 & + & + & - & 0 & + & - & + & \\
\hline & & & & & & - & - & - & 0 & - & - & + & - & + & - & + & - & \\
\hline & & & & & & & - & 0 & + & + & 0 & + & + & 0 & 0 & + & + & \\
\hline & & & & & & & & + & + & + & + & + & + & + & + & + & + & \\
\hline & & & & & & & & & + & 0 & + & + & 0 & + & 0 & + & + & \\
\hline & & & & & & & & & & - & + & - & + & - & 0 & + & + & \\
\hline & & & & & & & & & & & + & 0 & + & + & + & 0 & + & \\
\hline & & & & & & & & & & & & - & + & - & + & - & + & \\
\hline & & & & & & & & & & & & & - & - & + & - & + & \\
\hline & & & & & & & & & & & & & & + & + & 0 & + & \\
\hline & & & & & & & & & & & & & & & + & - & + & \\
\hline & & & & & & & & & & & & & & & & + & + & \\
\hline & & & & & & & & & & & & & & & & & + & \\
\hline
\end{tabular}


The estimated indicator, namely capital investment in agriculture, hunting and related services, $\%$ of the total investment in the region, which was selected for approval by the experts, is accepted because:

$$
R x=\frac{(N+)+(N-)}{N}
$$

where, $N=136$ - the total number of compounds from 17 to 2 (scale of experts 0.006-0.060);

$(N+)$ - number of positive agreements (in this case 80);

$(N-)$ - number of negative agreements (in this case 33).

Thus: $R x=(80-33) / 136=0,346-$ the estimated value is accepted because the calculated value of $R x \geq 0.3$.

In this case, the value of $R x \geq 0.3$ is determined according to the rank correlation, which is carried out according to Kendel.

According to the same principle of calculation of coherence, the examination for other estimation indicators of the regional development of the agro-industrial complex is carried out.
In accordance with the expert coordination of the evaluation indicators of the development of the agro-industrial complex, the indicators for evaluation were singled out and systematized (Fig. 1).

Thus, the separation of methodological principles for estimating the regional development of the agro-industrial complex and clarifying its list using the expert-statistical method, the estimated indicators of each area were chosen, which are presented in Table 3-6. All indicators are given in Table 3-6 were agreed by highly qualified specialists in accordance with the example given above (see Table 2, Formulas 1-2). It should be noted that in Tables 3-6 the indicators are presented according to how they received the largest number of agreed expert assessments. That is, for example, the index $\mathrm{x} 1$ received a better value of $\mathrm{Rx}$ than the indicator $\mathrm{x} 10$. However, it is possible to determine whether $\mathrm{x} 1$ has a greater impact on the agricultural sector and other industries that provide agricultural services than $\mathrm{x} 10$ only by calculating the correlation between the normalized values of evaluation indicators and finding the coefficients of their impact.

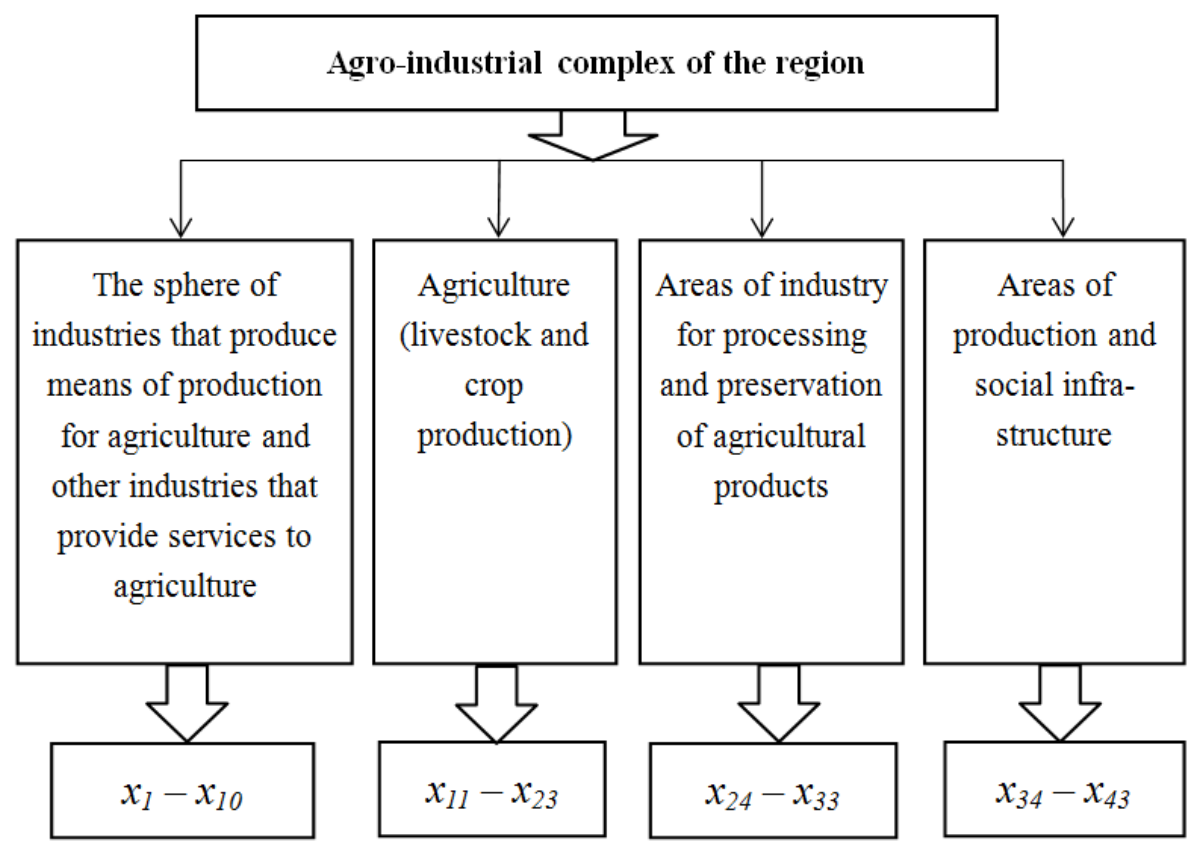

Figure 1. Block diagram of the structure of the evaluation system formation of the agro-industrial complex of regions 
Table 3. Estimates of the sphere of industries that produce means of production for agriculture and other industries that provide services to agriculture

\begin{tabular}{|c|l|}
\hline № & \multicolumn{1}{|c|}{ Indexes } \\
\hline$x_{1}$ & Capital investment in agriculture, hunting and related services, \% of total investment in the region \\
\hline$x_{2}$ & Innovatively active enterprises, in total, units \\
\hline$x_{3}$ & Purchase of new agricultural machinery by agricultural enterprises, pcs. \\
\hline$x_{4}$ & Availability of tractors, combines and agricultural machinery at agricultural enterprises, at the end of the year, pcs. \\
\hline$x_{5}$ & Sale of compound feeds to agricultural enterprises, thousand centners \\
\hline$x_{6}$ & Purchase of energy materials by agricultural enterprises, mln \\
\hline$x_{7}$ & Sales of petroleum products to agricultural enterprises, thousand tons \\
\hline$x_{8}$ & Purchase of mineral fertilizers by agricultural enterprises, thousand centners \\
\hline$x_{9}$ & Purchase of pesticide plant protection products by agricultural enterprises, thousand tons \\
\hline$x_{10}$ & Purchase of other chemical plant protection products by agricultural enterprises, thousand liters \\
\hline
\end{tabular}

Source: substantiated by the authors

Table 4. Estimates of agriculture (livestock, crop production)

\begin{tabular}{|l|l|}
\hline № & \multicolumn{1}{|c|}{ Indexes } \\
\hline$x_{11}$ & Meat production (in slaughter mass), thousand tons \\
\hline$x_{12}$ & Milk production, thousand tons \\
\hline$x_{13}$ & Egg production, mln. \\
\hline$x_{14}$ & Livestock products (at constant prices), UAH million \\
\hline$x_{15}$ & Financial results of livestock enterprises, net profit (loss), thousand UAH \\
\hline$x_{16}$ & Production of cereals and legumes, thousand tons \\
\hline$x_{17}$ & Production of sugar beets (factory), thousand tons \\
\hline$x_{18}$ & Sunflower production, thousand tons \\
\hline$x_{19}$ & Potato production, thousand tons \\
\hline$x_{20}$ & Vegetable production, thousand tons \\
\hline$x_{21}$ & Production of fruits and berries, thousand tons \\
\hline$x_{22}$ & Crop products (at constant prices), UAH million \\
\hline$x_{23}$ & Financial results of livestock enterprises, net profit (loss), thousand UAH \\
\hline
\end{tabular}

Source: substantiated by the authors

Table 5. Estimates of the sphere of industries for processing and preservation of agricultural products

\begin{tabular}{|l|l|}
\hline № & \multicolumn{1}{|c|}{ Indexes } \\
\hline $\mathrm{x}_{24}$ & Production of sausages, thousand tons \\
\hline $\mathrm{x}_{25}$ & Production of processed milk (pasteurized, sterilized, homogenized, rendered, peptized), thousand tons \\
\hline $\mathrm{x}_{26}$ & Production of fatty cheeses, thousand tons \\
\hline $\mathrm{x}_{27}$ & Production of unrefined sunflower oil and its fractions, thousand tons \\
\hline $\mathrm{x}_{28}$ & Flour production, thousand tons \\
\hline $\mathrm{x}_{29}$ & Production of bread and bakery products of short-term storage, thousand tons \\
\hline $\mathrm{x}_{30}$ & Production of white crystalline sugar, thousand tons \\
\hline $\mathrm{x}_{31}$ & Production of yogurt and other fermented or fermented milk and cream, thousand tons \\
\hline $\mathrm{x}_{32}$ & Production of food, beverages and tobacco, in\% to the previous year \\
\hline $\mathrm{x}_{33}$ & Textile production, production of clothing, leather, leather products and other materials, in\% to the previous year \\
\hline
\end{tabular}

Source: substantiated by the authors 
Table 6. Estimates of the sphere of production and social infrastructure

\begin{tabular}{|l|l|}
\hline № & \multicolumn{1}{|c|}{ Indexes } \\
\hline$x_{34}$ & Capital investment in education, \% of total investment in the region \\
\hline$x_{35}$ & Capital investments in professional, scientific and technical activities, \% of total investments in the region \\
\hline$x_{36}$ & Retail trade, except of motor vehicles and motorcycles, UAH mln \\
\hline$x_{37}$ & Capital investments in wholesale and retail trade, repair of motor vehicles, \% of total investments in the region \\
\hline$x_{38}$ & Capital investment in transport, warehousing, postal and courier activities, \% of total investment in the region \\
\hline$x_{39}$ & Capital investment in temporary accommodation and catering, \% of total investment in the region \\
\hline$x_{40}$ & Capital investments in health care and social assistance, $\%$ of total investments in the region \\
\hline$x_{41}$ & Commissioning of housing in rural areas, thousand m2 of total area \\
\hline$x_{42}$ & Capital investment in transport, warehousing, \% of total investment in the region \\
\hline$x_{43}$ & Capital investment in information and telecommunications, \% of total investment in the region \\
\hline
\end{tabular}

Source: substantiated by the authors

It should be noted that the indicators are certain evaluation indicators, namely: $x_{3}, x_{4}, x_{8}, x_{9}, x_{10}$, - are total indicators and include several or more components.

For example, the indicator $x 3$ - the purchase of new agricultural machinery by agricultural enterprises includes the purchase of the following vehicles: tractors of all types; plows; cultivators; harrows; drills; manure and fertilizer spreaders; water pumps and pumping stations; mowers; rollers; repackers; grain harvesters; grain cleaning machines, milking machines and devices; machines and mechanisms for feed preparation; manure conveyors; agricultural trailers and semi-trailers; trucks with diesel and semi-diesel internal combustion engines.

Indicator $x_{4}$ - the presence of tractors, combines and agricultural machinery in agricultural enterprises, at the end of the year, includes: tractors; grain and corn harvesters; beet harvesters; sprinkler systems and units; watering machines and devices; water pumps and pumping stations.

Indicators $x_{8}$ - purchase of mineral fertilizers by agricultural enterprises, contains: nitrogen, phosphate, potassium and complex fertilizers.

Indicators $x_{9}, x_{10}$ - purchase by agricultural enterprises of plant protection products, in thousands of tons and thousands of liters, includes: insecticides; fungicides; herbicides; plant growth regulators and other pesticides.

\section{Conclusions}

The scientific novelty of this study is the substantiation of the evaluation indicators system of the agro-industrial complex of regions, which, unlike the existing ones, is based on a methodological basis, which provides for the selection of evaluation indicators and coordination of groups of indicators using expert evaluation.

The grouping of indicators taking into account the principles of systematization, universality and coherence makes it possible, in addition to assessing the development of the agro-industrial complex of regions, also to assess individual areas, namely:

- firstly, industries that produce means of production for agriculture and other industries that provide services to agriculture;

- secondly, agriculture;

- thirdly, the spheres of industries for processing and preservation of agricultural products;

- fourthly, the sphere of production and social infrastructure.

The practical significance of this study is that a sound system of indicators can be used at the national and regional levels to calculate the development of the agro-industrial complex, and develop measures to improve its efficiency.

Further research requires calculations of the regional development of the agro-industrial complex, taking into account a sound system of evaluation indicators.

\section{REFERENCES}

[1] A.V. Belokopytov, N.V. Moskaleva, A.N. Ternovchuk. Effective conditions for expanded reproduction of the agro-industrial complex in the region, IOP Conference Series: Earth and Environmental Science, Vol.723(312), 032004, 2021.

[2] S. Tulchynska, O. Popelo, O. Vovk, B. Dergaliuk, I. Kreidych, T. Tkachenko. The Resource Supply of Innovation and Investment Strategies of the Microeconomic Systems Modernization in the Conditions of Digitalization, WSEAS TRANSACTIONS on ENVIRONMENT and DEVELOPMENT, Vol.17, 819-828, 2021.

[3] K. Dobrokvashina. Analysis of the effectiveness of state regulation of the agro-industrial complex on the example of several countries, E3S Web of Conferences, Vol.27322, 08013, 2021.

[4] U.A.S. Filho, L.T. Borges, P.P. Sesso, P.R.A. Brene, E.G.Z. Esteves. Measurement of the Agro-industrial Complex In The World: Comparative Between Countries, Revista de 
Economia e Sociologia Rural, Vol.60(1), 1-21, 2021.

[5] M. Kicha, N. Saraev, V. Tsechoev, G. Pratsko. Decriminalization of the agro-industrial complex as the most important factor in ensuring food security, E3S Web of Conferences, Vol.27322, 08075, 2021.

[6] E.P. Kiselitsa, N.N. Shilova, I.A. Liman, A.V. Kuprina, V.V. Vorona. Stimulating the innovative activity of enterprises in the agro-industrial complex, IOP Conference Series: Earth and Environmental Science, Vol.723(312), 032030, 2021.

[7] P. Krasnokutskiy, O. Tkacheva, N. Burianova, N. Yarovaya, A. Kazakova. Development of the regional agro-industrial complex in case of economic sanctions, E3S Web of Conferences, Vol.27322, 08024, 2021.

[8] O. Popelo, S. Tulchynska, Y. Kharchenko, B. Dergaliuk, S. Khanin, T. Tkachenko. Systemic Approach to Assessing Sustainable Development of the Regions, Journal of Environmental Management and Tourism, Vol.XII, Summer, 3(51), 742-753, 2021.

[9] O.R. Kuzichkin, V.T. Eremenko, G.S. Vasilyev, A.V. Eremenko, D.I. Surzhik. Modelling a transport-level telecommunication management service of thermoelectric systems in agro-industrial complex based on Petri nets, International Journal of Sustainable Agricultural Management and Informatics, Vol.7, No.2, 149-164, 2021.

[10] O. Popelo, S. Tulchynska, V. Marhasova, O. Garafonova, Y. Kharchenko. Public management of regional development in the conditions of the inclusive economy formation, Journal of Management Information and Decision Sciences, Vol.24(7), 1-8, 2021.

[11] S. Tulchynska, O. Popelo, V. Marhasova, O. Nusinova, Zh. Zhygalkevych. Monitoring of the Ecological Condition of Regional Economic Systems in the Context of Sustainable Development. Journal of Environmental Management and Tourism, 12(5), 1220-1228, 2021.

[12] T. Medvedskaya, E. Zaporozceva, N. Zemlyakova, O. Yuryeva. Functioning of the agro-industrial complex in the digital economy, E3S Web of Conferences, Vol.27322, 08034, 2021.

[13] M. Mushtruk, O. Deviatko, S. Ulianko, N. Kanivets, N. Mushtruk. An Agro-Industrial Complex Fat-Containing Wastes Synthesis Technology in Ecological Biofuel, Lecture Notes in Mechanical Engineering, 361-370, 2021.

[14] A. Revko, M. Butko, O. Popelo. Methodology for Assessing the Inflence of Cultural Infrastructure on Regional Development in Poland and Ukraine, Comparatie Economic Research. Central and Eastern Europe, Vol.23(2), 21-39, 2020.

[15] I.S. Sandu A.S. Troshin, Y.N. Bozhkov. Peculiarities of Digital Transformations in the Regional Agro-Industrial Complex, Studies in Systems, Decision and Control, Vol.283, 337-344, 2021
[16] E.G. Semyashkina, A.M. Karminskii. Modeling the rating system of export-oriented companies in the agro-industrial complex of the Russian Federation, Subsidy mechanism, Finance: Theory and Practice, Vol.25, No.3, 35-52, 2021.

[17] S. Shkarlet, N. Ivanova, O. Popelo, M. Dubina, O. Zhuk. Infrastructural and Regional Development: Theoretical Aspects and Practical Issues, Studies of Applied Economics, Vol.38(4), 2020.

[18] N. Shvydenko, D. Ananova, I. Sokolova. The specifics of forming a strategy for sustainable development of the regional agro-industrial complex, E3S Web of Conferences, Vol.27322, 08070, 2021.

[19] V. Smirnov, M. Danilina, I. Omelchenko, L. Botasheva. Economics of ecological and biological development and labor market of agro-industrial complex, E3S Web of Conferences, Vol.2035, 05011, 2020.

[20] V. Stadnyk, G Krasovska, P. Izhevskiy, T. Tomalia, L. Khomych, P. Matveev. Motivational aspects of development of strategic network partnership in the agro-industrial complex, Agricultural and Resource Economics, Vol.7, No.2, 77-101, 2021.

[21] I.I. Tsvetkova, M.Y. Vakhovskaya, A.V. Sivolap. Model for assessing personnel security of enterprises in the agro-industrial complex, IOP Conference Series: Earth and Environmental Science, vol.723(312), 032007, 2021.

[22] Y. Verchenko, M. Glyzina, A. Takmazyan, K. Samoylova. Evaluation of the effectiveness of innovative activities of companies in the agro-industrial complex in the context of the investment process, E3S Web of Conferences, Vol.27322, 08008, 2021.

[23] A. Viknianska, D. Kharynovych-Yavorska, M. Sahaidak, A. Zhavoronok, V. Filippov. Methodological approach to economic analysis and control of enterprises under conditions of economic systems transformation, Naukovyi Visnyk Natsionalnoho Hirnychoho Universytetu, Vol.4, 150-157, 2021.

[24] O. Vovk, M. Kravchenko, O. Popelo, S. Tulchynska, M. Derhaliuk. Modeling the Choice of the Innovation and Investment Strategy for the Implementation of Modernization Potential, WSEAS TRANSACTIONS on SYSTEMS and CONTROL, Vol.16, 430-438, 2021.

[25] S. Tulchynska, O. Popelo, O. Garafonova, V. Marhasova, T. Tkachenko. The impact of modernization on the competitiveness increase of the enterprise and provision of its economic security. Journal of Legal, Ethical and Regulatory Issues, 24(S5), 1-9, 2021.

[26] O. Solosich, O. Popelo, O. Nusinova, M. Derhaliuk, S. Tulchynska. Ensuring economic security of regions as a potential-forming space in the conditions of intellectualization. Academy of Entrepreneurship Journal, vol.27, No 6, 1-8, 2021. DOI: 1528-2686-27-6-617. 